\title{
Manufacture and Characterization of Pandan Wangi (Pandanus amaryllifolius Roxb) Fiber-Based Composite Board with Epoxy Resin
}

\author{
Timbangen Sembiring ${ }^{1^{*}}$, Perdinan Sinuhaji ${ }^{2}$ and Rahel Y Silitonga ${ }^{3}$ \\ ${ }^{1,2,3}$ Department of Physics, Faculty of Mathematics and Natural Science, Universitas Sumatera Utara \\ 20155, Indonesia
}

\begin{abstract}
The manufacture and characterization of pandan wangi fiber-based composite boards with epoxy resin using random fiber orientation method, fiber length $4 \mathrm{~cm}$, with fiber composition in grams $(0,0.1,0.2,0.3,0.4,0.5)$, mechanical and physical testing has been carried out. The results obtained a tensile strength value of $52.26 \mathrm{MPa}$, flexural strength $49.74 \mathrm{MPa}$, impact strength $30.6 \mathrm{~kJ} . \mathrm{mm}^{-2}$, density $1.07 \mathrm{~g} . \mathrm{cm}^{-3}$, and moisture content $2.05 \%$. The results showed that the mechanical and physical properties that meet the JIS A5905: 2003 standard are tensile strength > $0.4 \mathrm{MPa}$, bending strength > $32 \mathrm{MPa}$, density $0.3-1.3 \mathrm{~g}_{\mathrm{cm}}^{-3}$, and moisture content $5-13 \%$. Therefore, pandan wangi fiber composite with epoxy resin can be applied to car bumpers.
\end{abstract}

Keyword: epoxy, composite, pandan wangi fiber.

Received 22 October 2019 | Revised [19 November 2019] | Accepted [14 February 2020]

\section{Introduction}

Currently composite technology is developing. This is due to the increasing need for construction materials. The development of composite material technology recorded various innovative findings, even amazing ideas. Composite board promises special advantages, besides strength, it also has economic value and corrosion resistance [1].

Composite is a material that is formed from a combination of two or more forming materials through an inhomogeneous mixture, the mechanical properties of each of the forming materials are different [2-4]. From this mixture will produce a composite material that has different mechanical properties and characteristics from the forming material. In general, composites with fiber reinforcement are composed of the two main materials are matrix and fiber. Fibers that have higher strength act as reinforcing components, while weak matrices act as binders and give shape to the composite structure [5-6].

\footnotetext{
*Corresponding author at: Jalan Biolteknologi no.1 Medan, 20155, Indonesia

E-mail address: timbangen@usu.ac.id
} 
In general, composite materials consist of two elements, namely fillers and binders. Materials as reinforcement that can be used in the manufacture of composites are synthetic fibers and natural fibers or natural fibers. Environmentally friendly composite materials are usually based on natural fibers that can be obtained in the environment. Pandan wangi fiber (pandanus amaryllifolius Roxb) is an alternative natural fiber material in scientific composite making, its use is still being developed [7-8]. The resin used in this research is epoxy resin, because epoxy resin has a higher level of resistance or strength than other resins [9-10].

Based on the description above, an idea emerged to create and characterize a composite board based on pandan wangius fiber and epoxy resin. The purpose of this study was to determine the mechanical and physical properties of a composite board based on pandan wangius fiber and epoxy resin. While the practical benefits of this research can be used as a consideration for the industrial sector to use composites as a substitute for construction materials.

\section{Methods}

\subsection{Preparation of Pandan Wangi Fiber}

Selected old pandan wangi leaves with a length of $\pm 30 \mathrm{~cm}$, pandan wangi leaves are then cleaned and carried out soaking in mud for 9 days. The soaked pandan wangi leaves are then cleaned using running water and dried, after which the pandan wangi fibers are soaked using 5\% $\mathrm{NaOH}$ for 1.5 hours to remove the lignin content in the fibers. After the soaking process is complete, the pandan wangi fibers are washed using distilled water and dried. Pandan wangi fibers that have been dried are then cut into pieces $4 \mathrm{~cm}$ long.

\subsection{Manufacture of Pandan Wangi Fiber Composite Board}

Pandan wangi fibers are weighed according to the fiber mass determined using a digital balance, epoxy resin and hardener are weighed in a 1:1 ratio, then stirred using a stirrer until evenly distributed. The specimen mold is coated with wax and aluminum foil to prevent the sample from sticking to the mold. Pandan wangi fibers are arranged randomly and evenly on the mold, then pour the epoxy mixture with a hardener (without fiber) into the mold using a spatula, the mold is closed using a cover plate and placed on a hot press then pressed and set the temperature to $70^{\circ} \mathrm{C}$ for 60 minutes. The mold is removed from the press and left for 10 minutes. The sample is removed from the mold by removing the iron plate from the aluminum foil, then the aluminum foil is slowly pulled from the mold. Samples were made such as the first sample (without fiber), for the next sample with the composition of pandan wangi fiber $(0.1 ; 0.2 ; 0.3$; $0.4 ; 0.5)$ g. Furthermore, the resulting sample was characterized to see its mechanical and physical properties. 


\section{Result and Discussion}

\subsection{Mechanical Properties Testing}

The test results of the tensile strength of pandan wangi fiber composites with epoxy resin can be shown in the relationship between the tensile strength of the pandan wangi fiber composite epoxy resin with the composition of pandan wangi fibers as in Figure 1.

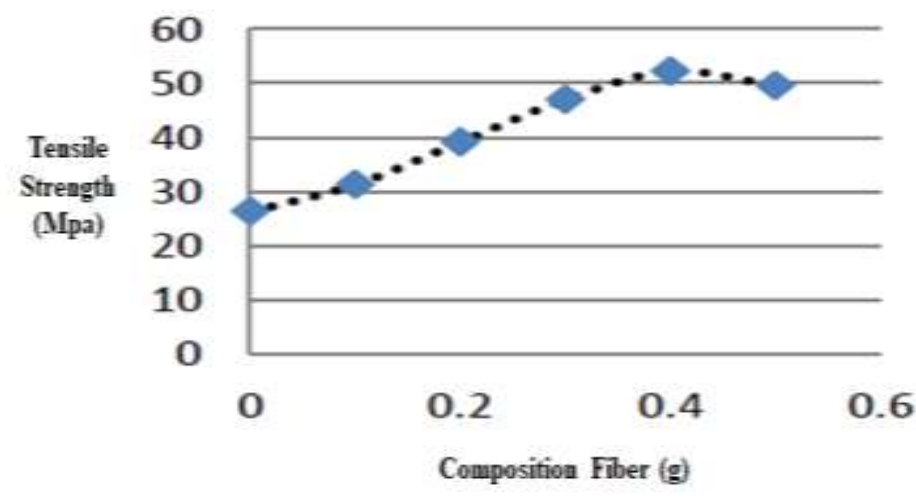

Figure 1. Graph of composite tensile strength vs composition of pandan wangi fiber

In Figure 1, it can be seen that the lowest tensile strength is in the composite without pandan wangi fiber, which is $26.4 \mathrm{MPa}$. The highest tensile strength in the pandan fragrant fiber composite with epoxy resin with a fiber composition of $0.4 \mathrm{~g}$, namely $52.26 \mathrm{MPa}$. The tensile strength of the composites increased with the increase in the composition of the pandan wangi fibers, but decreased in the composition of $0.5 \mathrm{~g}$, namely $49.6 \mathrm{MPa}$, this was due to the composition of the fibers that were too much so that the epoxy resin was unable to bind homogeneously. According to Japanese Industrial Standard JIS A5905: 2003, fiberboard requires a tensile strength greater than $0.4 \mathrm{MPa}$.

The flexural strength test results of pandan wangi fiber composites with epoxy resin are shown in Figure 2.

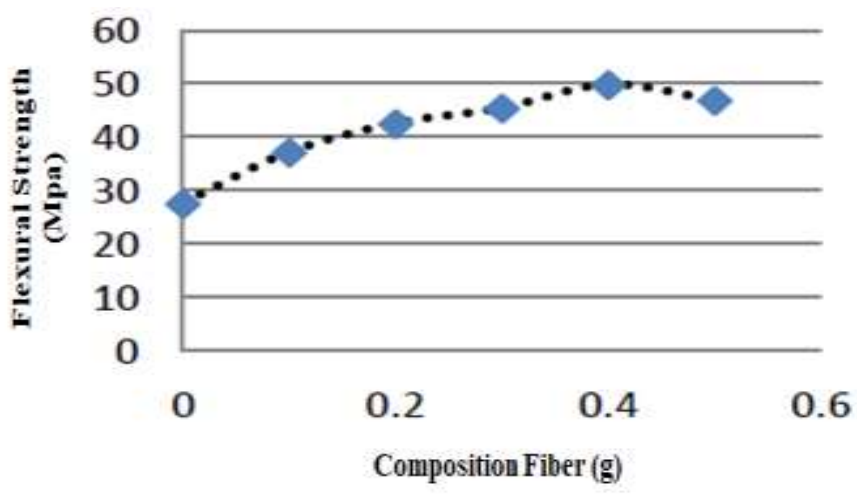

Figure 2. Graph of Composite Flexural Strength vs Composition of Wangi Pandan Fiber

From Figure 2, it can be seen that the highest flexural strength of the wangi pandan fiber composite - epoxy resin is found in the fiber composition of $0.4 \mathrm{~g}$, namely $49.74 \mathrm{MPa}$. The 
lowest flexural strength was found in the fiber-free composition, namely $27.51 \mathrm{MPa}$. The flexural strength of the composite increased with the increase in the pandan wangi fiber used, but decreased in the composition of $0.5 \mathrm{~g}$, namely $49.6 \mathrm{MPa}$. This is due to the composition of the fiber which is too much so that the epoxy resin is not able to bind homogeneously. Based on JIS A5905: 2003, several composites of wangi pandan fiber-epoxy resin with each variation of the composition of wangi pandan fibers have met the requirements for fiberboard with flexural strength greater than $35 \mathrm{MPa}$.

The test results of the impact strength of pandan wangi fiber composites with epoxy resin are shown in the relationship between the impact strength of the composites and the composition of the pandan wangi fibers as in Figure 3.

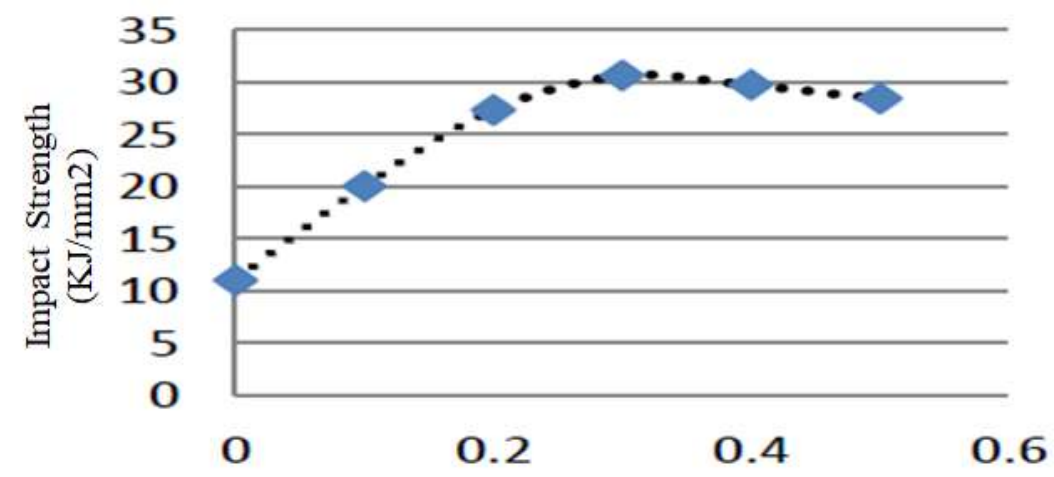

Figure 3. Composite Impact Strength Graph vs Composite Pandan Wangi Fiber

From Figure 3, the highest impact strength is the composite with a fiber composition of $0.3 \mathrm{~g}$, the lowest is the composition without fibers. The impact strength of the composites increases with the increase in the composition of the fibers used. However, there was a decrease in the composition of $0.4 \mathrm{~g}$ and $0.5 \mathrm{~g}$ of fiber composition, this was due to the presence of voids, which resulted in brittleness of the composite board. The increase in the composition of the fibers used in the specimen, the greater the specimen's ability to accept a given force.

\subsection{Physical Properties Testing}

The results of the density test of pandan wangi fiber composites with epoxy resin can be shown in the relationship between the density of pandan wangi fiber composites - epoxy resin with the composition of pandan wangi fibers as in Figure 4. 


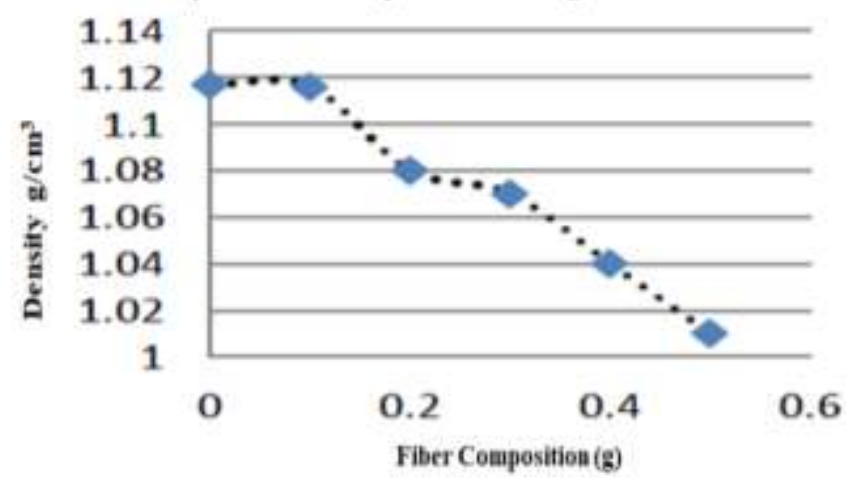

Figure 4. Composite density VS fiber composition of Pandan Wangi graph

From Figure 4, it can be seen that the highest density of pandan wangi fiber - epoxy resin composites is in the fiber-free composition, namely $1.117 \mathrm{~g} . \mathrm{cm}^{-3}$, while the lowest density is at the fiber composition of $0.5 \mathrm{~g}$, namely $1.01 \mathrm{~g} . \mathrm{cm}^{-3}$. In the pandan wangi fiber composite epoxy resin, the density decreased due to the increased use of fiber. If more fibers are used, the matrix will be less. The reduction in the matrix causes the mass of the composite to be less. The smaller the composite mass, while the composite volume remains, will cause the composite density to decrease. Pandan wangi fiber composite board - epoxy resin can be used as a fiberboard because it meets JIS A5905: 2003 which requires a fiber board density value of 0.35 g. $\mathrm{cm}^{-3}$ to $1.3 \mathrm{~g} . \mathrm{cm}^{-3}$. So, all the variations in the composition of the resulting pandan wangius fiber composites have met the specified requirements.

The results of water content testing of pandan wangi fiber composites with epoxy resin are shown in the relationship between the density of pandan wangi fiber composites - epoxy resin with the composition of pandan wangi fibers as in Figure 5.

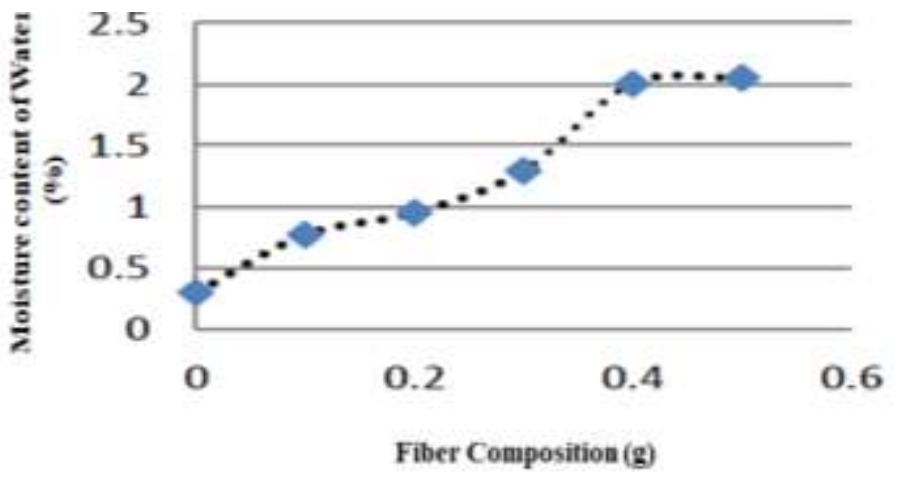

Figure 5. Graph of composite moisture content of water VS pandan wangi fiber composition From Figure 5, the highest moisture content value of the pandan wangi fiber composite - epoxy resin is in the composition of $0.5 \mathrm{~g}$, while the lowest water content is in the composition without fiber. So it can be concluded that the more fiber used, the higher the value of the moisture content that is owned. JIS A5905: 2003 requires a fiber board moisture content of 5 -13\%. From the test results, all composites with variations in composition qualify as fiberboard. 


\section{Conclusion}

From the results of the research carried out the mechanical properties and physical properties of pandan wangi fiber composites with epoxy resin, it can be concluded:

1. Pandan wangius fiber can be used as a natural fiber composite reinforcement.

2. The addition of pandan wangi fibers to the composition of pandan wangi fibers with epoxy resin greatly affects the mechanical properties, namely the highest tensile strength at 52.26 $\mathrm{MPa}$ at the composition of $0.4 \mathrm{~g}$, the highest flexural strength at $49.74 \mathrm{MPa}$ at the composition of $0.4 \mathrm{~g}$, the highest impact strength at $30.6 \mathrm{~kJ} . \mathrm{mm}^{2}$ at a composition of $1.38 \mathrm{~g}$.

3. The more fibers used, the higher the value of the mechanical strength, and the lower the density but the greater the water content.

4. Judging from the mechanical and physical properties of pandan wangi fiber composites with epoxy resin, it has a flexural strength of $49.74 \mathrm{MPa}$ and can be applied as a car bumper that has a flexural strength of approximately $32 \mathrm{MPa}$.

\section{REFERENCES}

[1] D. B. Dittenber and H. V. S. GangaRao, "Critical Review of Recent Publications on Use of Natural Composites in Infrastructure," Composites Part A: Applied Science and Manufacturing, vol. 43, no. 8, pp. 1419-1429, 2012.

[2] J. R. Vinson and T. W. Chou, Composite Materials and Their Use in Structures, New York: Halsted Press, 1975.

[3] D. Hull and T. W. Clyne, An Introduction to Composite Materials $2^{\text {nd }}$ Edition, England: Cambridge University Press, 2019.

[4] B. Widodo, "Analisa Sifat Mekanik Komposit Epoksi dengan Penguat Serat Pohon Aren (Ijuk) Model Lamina Berorientasi Sudut Acak (Random)," Jurnal Teknologi Technoscientia, vol. 1, no. 1, pp. 1-5, 2008.

[5] M. M. Schwartz, Composite Materials Handbook, New York: Mc Graw Hill Inc, 1984.

[6] M. P. Ho, H. Wang, J. H. Lee, C. K. Ho, K. T. Lau, J. Leng and D. Hui, "Critical Factors on Manufacturing Processes of Natural Fibre Composites," Composites Part B: Engineering, vol. 43, no. 8, pp. 3549-3562, 2012.

[7] E. D. Sulistyowati, N. H. Sari, I. G. N. K. Yudhyadi, S. Sinarep and T. Topan, "Pengaruh Panjang Serat dan Fraksi Volume Terhadap Kekuatan Impact dan Bending Material Komposit Polyester-Fiber Glass dan Polyester-Pandan Wangi," Dinamika Teknik Mesin: Jurnal Keilmuan dan Terapan Teknik Mesin, vol. 2, no. 1, pp. 1-13, 2012.

[8] N. A. B. A. Shukor, Xanthine Oxidase Inhibitory Activity of Pandanus Amaryllifolius Roxb, Kuala Lumpur: University of Malaya, 2017.

[9] T. Surdia and S. Shinroku, Pengetahuan Bahan Teknik, Jakarta : PT. Pradnya Paramita, 1985.

[10] D. D. L. Chung, Composite Materials, Science and Applications $2^{\text {nd }}$ Edition, New York: Springer-Verlag London Limited, 2010. 